RESEARCH ARTICLE

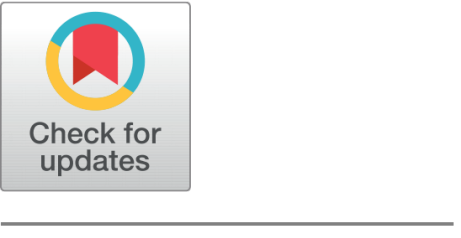

G OPEN ACCESS

Received: 18.08.2021

Accepted: 04.12.2021

Published: 27.12 .2021

Citation: Addis Y, Sani S (2021) Impact of Adoption of Improved Agricultural Production

Technologies on Cereal Crops Productivity and Farmers' Welfare in Central Ethiopia. Indian Journal of Science and Technology 14(44): 3280-3287. https://doi.org/ 10.17485/IJST/v14i44.1306

* Corresponding author.

yonnas.addis@wku.edu.et

Funding: None

Competing Interests: None

Copyright: ๑ 2021 Addis \& Sani. This is an open access article distributed under the terms of the Creative Commons Attribution License, which permits unrestricted use, distribution, and reproduction in any medium, provided the original author and source are credited.

Published By Indian Society for Education and Environment (iSee)

ISSN

Print: 0974-6846

Electronic: 0974-5645

\section{Impact of Adoption of Improved Agricultural Production Technologies on Cereal Crops Productivity and Farmers' Welfare in Central Ethiopia}

\author{
Yonnas Addis ${ }^{*}{ }^{*}$, Seid Sani ${ }^{2}$ \\ 1 Department of Agribusiness and Value Chain Management, Wolkite University, Ethiopia \\ 2 Assistant professor of Agricultural Economics, Wolkite University, Woklite, Ethiopia
}

\begin{abstract}
Objectives: To analyze the impact of a single and/or bundle of technologies on the productivity and welfare of farmers, and to check its heterogeneous impact on productivity and farmers' welfare. Methods: A Multinomial Endogenous Switching Regression (MESR) was employed to analyze the data collected from a total of 400 cereal crops producing farmers in the north Shewa zone of Ethiopia. Findings: The analysis showed that compared to the non-adopter farmers, a better net cereals crop income per land was obtained from the simultaneous adoption of improved seed and row planting, row planting and urea, and improved seed, and row planting and urea. For instance, compared to the counterfactual scenario of non-adopter, the mixed adoption of an improved seed variety with row planting technology increases net cereal crop income of farmers by about birr 14479.64 per cultivated land. The result also confirmed that a slight increase in welfare was recorded when cerealproducing farmers adopt improved agricultural technologies compared to a counterfactual scenario of non-adopters. The consumption expenditure per adult equivalent for raw planting technology adopters increases by Birr 567.69 compared to the counterfactual scenario of non-adopters. Novelty: The study provides empirical evidence about the possible role of using different adoption technology packages jointly on productivity and welfare. Sustainable and simultaneous adaptations of improved agricultural technologies need to be promoted for better farm productivity and welfare of households.
\end{abstract}

Keywords: Ethiopia; Impact; Improved technology; Productivity; Welfare

\section{Introduction}

Nowadays, the productivity and welfare of rural households highly depends on the use of improved agricultural technologies ${ }^{(1)}$.A recent study by USAID reported that agriculture in Ethiopia contributed to the livelihoods of more than $70 \%$ of the Ethiopians, $35.7 \%$ of the GDP and $90 \%$ of foreign exchange earnings ${ }^{(2)}$. Furthermore, in most developing countries, the rest of the economy like the food processing subsector 
depends on the agriculture sector as it contributes to providing inputs and increasing the supply of affordable food in Ethiopia ${ }^{(3)}$. However, in these countries, agricultural production is still subsistence oriented and less productive due to the lower level of technology adoption because of socio-economic, institutional and demographic factors ${ }^{(4)}$.

A better rural household welfare which is marked by improving the productivity of the agricultural sector calls for the adoption of improved agricultural production technologies ${ }^{(4,5)}$. Among improved agricultural production technologies, improved (early maturing, drought-resistant, etc.) crop varieties, agricultural mechanization (row planting technology), soil and water conservation practices (minimum tillage, mulching, etc.), organic and inorganic fertilizers are among the main improved agricultural technologies mainly practiced by smallholder farmers in Ethiopia. The adoption of either of the abovementioned improved agricultural technologies revealed a positive effect on productivity ${ }^{(6-8)}$ and farmers' welfare ${ }^{(9-11)}$. Also, effective improved agricultural production technologies enhance marketable surplus production by smallholders ${ }^{(12)}$.

Many of the literatures in the field of adoption of improved agricultural agricultural technologies revealed the positive effect of technology adoption on crop productivity and farmers' welfare. However, a small amount of empirical evidence is presented on the impact of adoption of multiple corresponding agricultural production technologies on productivity and welfare ${ }^{(13)}$. The adoption of multiple improved agricultural technologies simultaneously is more economical and could have a higher impact on agricultural production and wellbeing. Exploration of the impact of adoption of multiple agricultural technologies at a time would be helpful for policy makers as different agricultural technologies can have complementary characteristics. Thus, it is undoubtedly that identifying technologies having a complimentary nature and the possible impact of adoption of multiple production technologies is required for attaining sustainability and increased food production ${ }^{(14)}$.

The innovation, adoption, and promotion of improved agricultural production technologies in Ethiopia mainly target cereal crops. According to the Central Statistical Agency report of 2017, cereals occupy about $81.27 \%$ of the total acreage of all grain crops (cereals, oilseeds, and pulses) and account for $87.42 \%$ of the total annual production ${ }^{(15)}$. About 95 percent of cereal crop production comes from smallholder farmers, but they are relatively the economically disadvantaged groups in the crop value chain. Hence, identifying complementary improved agricultural technologies, their potential impact and encouraging smallholder adoption of such improved technologies is required for better productivity of cereals and farmers' welfare.

Smallholder cereal producing farmers of Ethiopia have adopted somewhat improved agricultural production technologies in spite of the variation in the intensity of adoption and adoption technology choice ${ }^{(16)}$. However, the majority of smallholders practiced only a single technology rather than full technology packages, including the study area, in the North Shewa zone of Ethiopia ${ }^{(17)}$. Each improved agricultural production technology showed a positive impact on productivity and farmers' welfare,but complementary agricultural technologies can have more impact on it ${ }^{(13)}$. In spite of the area's potential for cereal crop production, there is limited empirical study of this topic in the north Shewa zone. Shortage of empirical evidence about the impact of using a combination of multiple improved agricultural production technologies on productivity and welfare in many parts of Ethiopia, including the north Shewa zone, has created a knowledge gap on the adoption level and restricted smallholder realistic economic advantage from their crop produce. Therefore, this study aimed at analyzing the impact of adoption of the improved agricultural production technologies and scrutinized such improved technologies on cereals productivity and welfare.

\section{Materials and Methods}

\subsection{Study area}

The empirical data used for this study were collected from a sample of improved agricultural technology users and non-users in the North Shewa Zone of Oromia, Ethiopia (Figure 1). Three districts of North Shewa Zone namely, Wuchale, Degem, and Kimbibit were considered in this study. These districts were selected as they are the primary producers of cereal crops in the zone, and they relatively adopt improved agricultural technologies in the North Shewa zone ${ }^{(17)}$. In these sampled three districts, cereals namely Teff, maize, wheat, barley and pulse crops are largely produced ${ }^{(18)}$. 


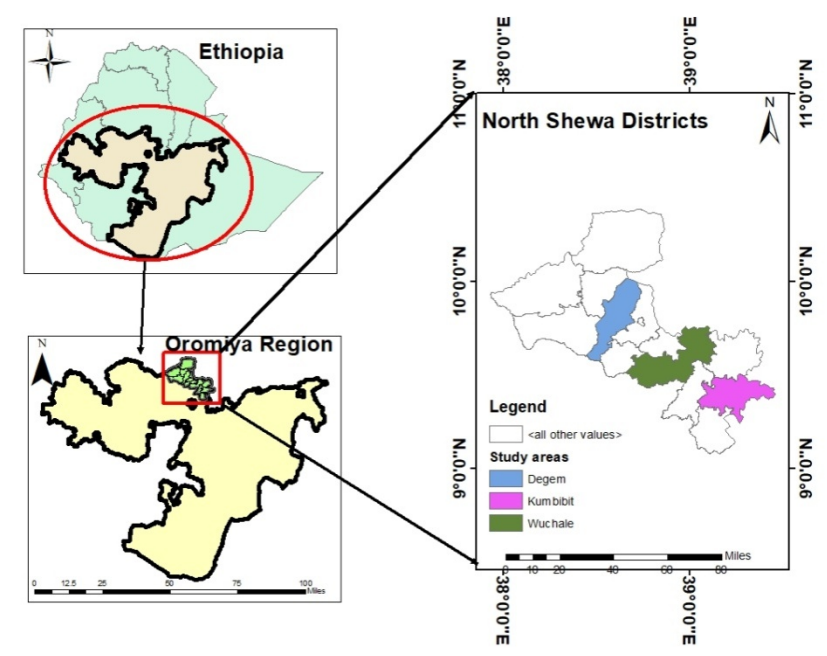

Fig 1. Location map of the study area

\subsection{Sampling technique and Methods of Collection}

The study employed a stratified multistage sampling procedure for farmers sampling. In the first stage, in consultation with north shewa zone Agriculture office, three potentials cereal producing districts, namely, Wuchale, Degem, and Kimbibit were selected from north Shewa zone. In second stage, considering the number of cereal producing kebeles of the selected districts, their production potential of cereals, and the status of technology adoption, a total of 10 kebeles ( 4 from Wuchale, 3 from Degem and 3 from Kimbibit) were selected purposively. Thirdly, having the list of cereal-producing farmers in the respective sampled kebeles with the consultation of the kebele agricultural office; cereals-producing farmers were stratified into non-adopters and adopters of at least a single technology. Finally, from each sampled kebeles 25 adopters and 15 non-adopters were randomly selected giving the total of 400 farming households (250 adopters and 150 non-adopters). This is done the number as the number of adopters and none adopters in sampled districts are nearly similar and assumed as representatives of the population. The primary data used in this study were collected by using interview schedules through enumerators and researchers from cereal producing farmers of the study area. Secondary data were taken from international, national, zonal reports to strengthen the report of this study.

\subsection{Data Analysis}

In non-experimental researches, consideration of the possible bias from the differences between the counterfactual for treated units and observed outcomes for untreated units is very important. Ignoring the possible, such selection bias in the analysis leads to inconsistent estimates of the impact of program intervention on the outcome variables ${ }^{(19)}$. For instance, sampled farmers were not randomly distributed into the treatment and controlled groups, rather they made their own choices or were systematically selected based on their tendency to participate in the program. Considering the information indicated above, this study used a multinomial endogenous switching regression (MESR) model to evaluate the impact of improved agricultural technology adoption on agricultural productivity and farmers' welfare. The maximum likelihood (FIML) estimator of the MESR model is employed to simultaneously calculate the selection and outcome equations ${ }^{(16,20,21)}$.

In order to estimate unbiased regression coefficients, this is calculated in the second stage of MESR model, the selection correction term which is estimated in the first stage of MESR model is used. MESR also enables us to identify the complementary effects between specific technologies used, since the simultaneous adoption of two technologies could result in different outcomes when compared to the addition of the effects of each technology adopted in isolation ${ }^{(22-24)}$. Household is likelihood of adopting technology $\mathrm{j}$ (with $\mathrm{j}=0,1,2 \ldots \mathrm{J}$ is estimated by using a multinomial logit model (for each technology adopted and their combinations).

$$
P\left(J=j / X_{i j}\right)=p_{i j}=\frac{\exp \left(\alpha_{j}+X_{i j} \beta_{j}+\varepsilon_{i j}\right)}{\sum_{j=1}^{J} \exp \left(\alpha_{j}+X_{i j} \beta_{j}+\varepsilon_{i j}\right)}, \text { for } j=0,1,2 \ldots J
$$


Where; the likelihood of the household $\mathrm{i}$ choosing the technology set $\mathrm{j}$ is represented by pij. $\mathrm{X}_{i j}$ is a matrix of observable household demographic, social, economic, and institutional factors affecting the choice of technology sets, $\varepsilon$ ij represents the error term (from unobservable factors and random error term). With selection bias correction, the output equations for each possible technology using decision $\mathrm{j}$ is specified as,

$$
\text { Regime 0: } \quad y_{i 0}=Z_{i 0} \beta_{0}+\omega_{0} \lambda_{i 0}+w_{i 0} \text { if } j=0
$$

$$
\text { Regime J: } \quad y_{i j}=Z_{i j} \beta_{j}+\omega j \lambda_{i j}+w_{i j} \text { if } j=1, \ldots \ldots, J
$$

Where; $j=0$ represents farmers who didn't use either of the proposed technologies or their combinations, $(j=1,2, \ldots J)$ represents farmers who used either of any technology or a combination of technologies, while Yij represents the outcomes related to the selected regime $\mathrm{j}(\mathrm{j}=0, \ldots, \mathrm{J})$. Zi represents a vector of control variables and $\lambda i$ is the selection bias correction term estimated from the first stage.

Following the approaches used by ${ }^{(25)}$ and ${ }^{(26)}$, this study used the household's net income from crop per land covered by cereal crops for an outcome-variable measurement. Also, the study relied on consumption expenditure per adult equivalent unit (AEU) which is regarded as a good proxy variable to represent the welfare of the households. The dependent variables used variable was technology adoption, which is a categorical variable indicating either of the proposed improved agricultural production technologies or a combination of them. The study considered improved variety, row planting technology, and application of urea after weeding as improved production agricultural technologies.

\section{Results and Discussion}

\subsection{Description of Covariates by Technology Set}

Among non- adopter farming households, about $80 \%$ were males, this is relatively lower than all categories of adopter farmers except adopters of a combination of row planting and urea after weeding. The result confirmed that the mean age of non-adopter farmers (47.47 years) was higher than the pooled mean age. The study result also showed out that the average family size (in adult equivalent) of sampled farmers was 5.53 members, and it is higher than the mean family size (in adult equivalent) of non-adopter farmers (5.028 members). The result confirmed that the mean experience of farmers in all categories except for combined adopters of improved seed row planting (22.26 years) and improved seed \& urea after weeding (18.79 years) was higher than non-adopter farmers' mean experience in cereal crops production.

Moreover, the TLU of livestock owned by households who adopted a combination of row planting \& urea after weeding (14.53) and improved seed, row planting \& urea after weeding (11.4) was higher than other categories. Furthermore, 73\% of the farmers reported that the slope of their land is plain, but this proportion is lower than non-adopter farmers that confirm that their land is flat. Among adopters, only 19.5\% of them accessed credit in cash and in-kind, which is lower than the proportion of non-adopter farmers, which was about $22 \%$ (Table 1 ).

\begin{tabular}{|c|c|c|c|c|c|c|c|c|c|}
\hline \multirow[b]{2}{*}{ Variables } & \multicolumn{8}{|c|}{ Technology sets } & \multirow[b]{2}{*}{ Total } \\
\hline & A0 & A1 & A2 & A3 & A4 & A5 & A6 & A7 & \\
\hline \multirow[t]{2}{*}{ sex of the hh head } & 0.800 & 1 & 1 & 1 & 0.941 & 0.939 & 0.767 & 0.853 & 0.870 \\
\hline & $(0.401)$ & $(0)$ & $(0)$ & $(0)$ & $(0.239)$ & $(0.242)$ & $(0.430)$ & $(0.356)$ & $(0.337)$ \\
\hline \multirow{2}{*}{ Age of the hh head } & 47.47 & 50.38 & 47.27 & 47.48 & 41.18 & 47.58 & 49.60 & 47.60 & 47.27 \\
\hline & $(10.57)$ & $(9.698)$ & $(7.418)$ & $(8.586)$ & $(8.562)$ & $(12.45)$ & $(8.156)$ & $(7.896)$ & $(9.707)$ \\
\hline \multirow{2}{*}{$\begin{array}{l}\text { Family size in adult } \\
\text { equivalent }\end{array}$} & 5.028 & 5.812 & 6.335 & 5.976 & 6.222 & 4.176 & 5.501 & 6.266 & 5.530 \\
\hline & $(2.110)$ & $(2.318)$ & $(2.019)$ & $(1.756)$ & $(1.613)$ & $(0.990)$ & $(1.410)$ & $(1.755)$ & $(1.973)$ \\
\hline \multirow{2}{*}{ Education of the hh head } & 3.347 & 5.238 & 4.233 & 3 & 3.647 & 4.394 & 3.667 & 4.307 & 3.805 \\
\hline & $(3.472)$ & $(3.404)$ & $(3.540)$ & $(2.922)$ & $(3.218)$ & $(4.723)$ & $(3.407)$ & $(3.491)$ & (3.553) \\
\hline \multirow{2}{*}{ Education of spouse } & 0.200 & 0.0952 & 0.167 & 0.333 & 0.382 & 0.545 & 0.400 & 0.360 & 0.290 \\
\hline & $(0.401)$ & $(0.301)$ & $(0.379)$ & $(0.480)$ & $(0.493)$ & $(0.506)$ & $(0.498)$ & $(0.483)$ & $(0.454)$ \\
\hline \multirow{2}{*}{$\begin{array}{l}\text { Experience in cereal } \\
\text { crops production }\end{array}$} & 23.91 & 32.57 & 28.37 & 28.07 & 22.26 & 18.79 & 25.60 & 26.08 & 24.95 \\
\hline & $(12.02)$ & $(12.16)$ & $(9.565)$ & $(8.940)$ & (7.997) & $(10.50)$ & $(8.365)$ & $(9.184)$ & $(10.82)$ \\
\hline
\end{tabular}

Table 1. Description and summary of variables 


\begin{tabular}{|c|c|c|c|c|c|c|c|c|c|}
\hline \multicolumn{10}{|c|}{ Table 1 continued } \\
\hline $\begin{array}{l}\text { Responsibility of the hh } \\
\text { in the community }\end{array}$ & $\begin{array}{l}0.513 \\
(0.501)\end{array}$ & $\begin{array}{l}0.476 \\
(0.512)\end{array}$ & $\begin{array}{l}0.567 \\
(0.504)\end{array}$ & $\begin{array}{l}0.519 \\
(0.509)\end{array}$ & $\begin{array}{l}0.882 \\
(0.327)\end{array}$ & $\begin{array}{l}0.727 \\
(0.452)\end{array}$ & $\begin{array}{l}0.100 \\
(0.305)\end{array}$ & $\begin{array}{l}0.413 \\
(0.496)\end{array}$ & $\begin{array}{l}0.515 \\
(0.500)\end{array}$ \\
\hline Cooperative & 0.800 & 1 & 0.833 & 0.778 & 0.853 & 0.485 & 0.0667 & 0.733 & 0.723 \\
\hline membership status of & $(0.401)$ & $(0)$ & $(0.379)$ & $(0.424)$ & $(0.359)$ & $(0.508)$ & $(0.254)$ & $(0.445)$ & $(0.448)$ \\
\hline $\begin{array}{l}\text { the } H H \text { head } \\
\text { TLU of livestock owned }\end{array}$ & $\begin{array}{l}8.821 \\
(6.417)\end{array}$ & $\begin{array}{l}8.757 \\
(5.551)\end{array}$ & $\begin{array}{l}9.927 \\
(7.168)\end{array}$ & $\begin{array}{l}10.15 \\
(6.804)\end{array}$ & $\begin{array}{l}7.974 \\
(3.584)\end{array}$ & $\begin{array}{l}7.651 \\
(5.157)\end{array}$ & $\begin{array}{l}14.53 \\
(5.336)\end{array}$ & $\begin{array}{l}11.40 \\
(7.945)\end{array}$ & $\begin{array}{l}9.732 \\
(6.625)\end{array}$ \\
\hline Land size & $\begin{array}{l}2.572 \\
(1.327)\end{array}$ & $\begin{array}{l}2.488 \\
(1.343)\end{array}$ & $\begin{array}{l}2.065 \\
(1.349)\end{array}$ & $\begin{array}{l}3.007 \\
(1.851)\end{array}$ & $\begin{array}{l}2.140 \\
(0.764)\end{array}$ & $\begin{array}{l}3.242 \\
(1.961)\end{array}$ & $\begin{array}{l}3.050 \\
(1.663)\end{array}$ & $\begin{array}{l}2.671 \\
(1.513)\end{array}$ & $\begin{array}{l}2.632 \\
(1.479)\end{array}$ \\
\hline Cultivated land size & $\begin{array}{l}1.888 \\
(0.967)\end{array}$ & $\begin{array}{l}1.310 \\
(0.524)\end{array}$ & $\begin{array}{l}1.592 \\
(1.037)\end{array}$ & $\begin{array}{l}2.389 \\
(1.652)\end{array}$ & $\begin{array}{l}1.684 \\
(0.548)\end{array}$ & $\begin{array}{l}2.273 \\
(1.278)\end{array}$ & $\begin{array}{l}2.650 \\
(1.463)\end{array}$ & $\begin{array}{l}2.043 \\
(1.357)\end{array}$ & $\begin{array}{l}1.970 \\
(1.171)\end{array}$ \\
\hline $\begin{array}{l}\text { Fertility status of the } \\
\text { land }\end{array}$ & $\begin{array}{l}1.873 \\
(0.627)\end{array}$ & $\begin{array}{l}1.762 \\
(0.539)\end{array}$ & $\begin{array}{l}1.933 \\
(0.521)\end{array}$ & $\begin{array}{l}1.889 \\
(0.751)\end{array}$ & $\begin{array}{l}2.147 \\
(0.500)\end{array}$ & $\begin{array}{l}1.970 \\
(0.305)\end{array}$ & $\begin{array}{l}2.267 \\
(0.583)\end{array}$ & $\begin{array}{l}1.907 \\
(0.791)\end{array}$ & $\begin{array}{l}1.940 \\
(0.634)\end{array}$ \\
\hline Land slope & $\begin{array}{l}0.760 \\
(0.429)\end{array}$ & $\begin{array}{l}0.524 \\
(0.512)\end{array}$ & $\begin{array}{l}0.733 \\
(0.450)\end{array}$ & $\begin{array}{l}0.815 \\
(0.396)\end{array}$ & $\begin{array}{l}0.588 \\
(0.500)\end{array}$ & $\begin{array}{l}0.667 \\
(0.479)\end{array}$ & $\begin{array}{l}0.833 \\
(0.379)\end{array}$ & $\begin{array}{l}0.747 \\
(0.438)\end{array}$ & $\begin{array}{l}0.730 \\
(0.445)\end{array}$ \\
\hline Access to credit & $\begin{array}{l}0.220 \\
(0.416)\end{array}$ & $\begin{array}{l}0.333 \\
(0.483)\end{array}$ & $\begin{array}{l}0.367 \\
(0.490)\end{array}$ & $\begin{array}{l}0.222 \\
(0.424)\end{array}$ & $\begin{array}{l}0.0588 \\
(0.239)\end{array}$ & $\begin{array}{l}0.0606 \\
(0.242)\end{array}$ & $\begin{array}{l}0.200 \\
(0.407)\end{array}$ & $\begin{array}{l}0.147 \\
(0.356)\end{array}$ & $\begin{array}{l}0.195 \\
(0.397)\end{array}$ \\
\hline $\begin{array}{l}\text { Access to mkt } \\
\text { information }\end{array}$ & $\begin{array}{l}0.813 \\
(0.391)\end{array}$ & $\begin{array}{l}0.810 \\
(0.402)\end{array}$ & $\begin{array}{l}0.867 \\
(0.346)\end{array}$ & $\begin{array}{l}1 \\
(0)\end{array}$ & $\begin{array}{l}0.676 \\
(0.475)\end{array}$ & $\begin{array}{l}0.879 \\
(0.331)\end{array}$ & $\begin{array}{l}1 \\
(0)\end{array}$ & $\begin{array}{l}0.933 \\
(0.251)\end{array}$ & $\begin{array}{l}0.860 \\
(0.347)\end{array}$ \\
\hline Access to training & $\begin{array}{l}0.947 \\
(0.225)\end{array}$ & $\begin{array}{l}1 \\
(0)\end{array}$ & $\begin{array}{l}0.933 \\
(0.254)\end{array}$ & $\begin{array}{l}1 \\
(0)\end{array}$ & $\begin{array}{l}0.706 \\
(0.462)\end{array}$ & $\begin{array}{l}1 \\
(0)\end{array}$ & $\begin{array}{l}1 \\
(0)\end{array}$ & $\begin{array}{l}0.973 \\
(0.162)\end{array}$ & $\begin{array}{l}0.945 \\
(0.228)\end{array}$ \\
\hline $\begin{array}{l}\text { Distance from the } \\
\text { market }\end{array}$ & $\begin{array}{l}16.28 \\
(18.51)\end{array}$ & $\begin{array}{l}11.19 \\
(15.49)\end{array}$ & $\begin{array}{l}13.23 \\
(19.16)\end{array}$ & $\begin{array}{l}20.24 \\
(23.04)\end{array}$ & $\begin{array}{l}11.79 \\
(11.54)\end{array}$ & $\begin{array}{l}27.36 \\
(25.81)\end{array}$ & $\begin{array}{l}51.57 \\
(8.480)\end{array}$ & $\begin{array}{l}18.71 \\
(25.63)\end{array}$ & $\begin{array}{l}19.69 \\
(22.16)\end{array}$ \\
\hline $\begin{array}{l}\text { Frequency of extension } \\
\text { contact }\end{array}$ & $\begin{array}{l}9.973 \\
(8.079)\end{array}$ & $\begin{array}{l}5.476 \\
(5.845)\end{array}$ & $\begin{array}{l}5.267 \\
(5.539)\end{array}$ & $\begin{array}{l}6.778 \\
(5.430)\end{array}$ & $\begin{array}{l}6.029 \\
(4.589)\end{array}$ & $\begin{array}{l}9.212 \\
(6.716)\end{array}$ & $\begin{array}{l}15.20 \\
(6.099)\end{array}$ & $\begin{array}{l}5.800 \\
(5.365)\end{array}$ & $\begin{array}{l}8.380 \\
(7.157)\end{array}$ \\
\hline $\begin{array}{l}\text { Confidence on extension } \\
\text { services }\end{array}$ & $\begin{array}{l}0.667 \\
(0.473)\end{array}$ & $\begin{array}{l}0.762 \\
(0.436)\end{array}$ & $\begin{array}{l}0.667 \\
(0.479)\end{array}$ & $\begin{array}{l}0.630 \\
(0.492)\end{array}$ & $\begin{array}{l}0.735 \\
(0.448)\end{array}$ & $\begin{array}{l}0.970 \\
(0.174)\end{array}$ & $\begin{array}{l}0.500 \\
(0.509)\end{array}$ & $\begin{array}{l}0.760 \\
(0.430)\end{array}$ & $\begin{array}{l}0.705 \\
(0.457)\end{array}$ \\
\hline $\begin{array}{l}\text { Distance from FTC } \\
\text { center }\end{array}$ & $\begin{array}{l}17.36 \\
(18.69)\end{array}$ & $\begin{array}{l}5.143 \\
(5.099)\end{array}$ & $\begin{array}{l}8.067 \\
(10.37)\end{array}$ & $\begin{array}{l}12.28 \\
(14.19)\end{array}$ & $\begin{array}{l}10.41 \\
(8.911)\end{array}$ & $\begin{array}{l}10.58 \\
(8.899)\end{array}$ & $\begin{array}{l}26.17 \\
(16.54)\end{array}$ & $\begin{array}{l}11.85 \\
(13.60)\end{array}$ & $\begin{array}{l}14.15 \\
(15.65)\end{array}$ \\
\hline $\begin{array}{l}\text { Experience in FTC } \\
\text { trainings }\end{array}$ & $\begin{array}{l}7.713 \\
(2.932)\end{array}$ & $\begin{array}{l}7.476 \\
(2.337)\end{array}$ & $\begin{array}{l}7.967 \\
(1.810)\end{array}$ & $\begin{array}{l}8.593 \\
(1.647)\end{array}$ & $\begin{array}{l}8.265 \\
(1.563)\end{array}$ & $\begin{array}{l}5.879 \\
(2.342)\end{array}$ & $\begin{array}{l}8.733 \\
(1.363)\end{array}$ & $\begin{array}{l}8.667 \\
(1.796)\end{array}$ & $\begin{array}{l}7.930 \\
(2.417)\end{array}$ \\
\hline Observations & 400 & & & & & & & & \\
\hline
\end{tabular}

Source: Computed result (2020)

\subsection{Cereal Crops Productivity and Welfare of Farmers}

Table 2 represents the net cereal crops income per cultivated land and consumption expenditure per adult equivalent by technology sets used. The average net cereal crops income per cultivated land of the farmers was birr 12,295.4 with higher and lower mean net cereal crops income per cultivated land of birr 24679.3 and 9604.1 for adopters, and non-adopter farmers, respectively. The result indicates that the mean net cereal crops income per cultivated land of non-adopter farmers is lower than adopters of any technology set.

On average, adopter farmers spent a consumption expenditure per adult equivalent of birr 1859.8 with a maximum of birr 2783.7 for only adopters of improved seed verities and a minimum of birr 476.5 for mixed adopters of row planting technology and urea after weeding. The mean consumption expenditure per adult equivalent for farmers who adopted both row planting technology and urea after weeding at a time was lower than non-adopter farmers (which was about birr 1739.9). This could be due to the reason that using multiple technologies at a time increases the cost of production, and this decreases the amount of net income per cultivated land and consumption expenditure per adult equivalent of farming households. Generally, the finding indicates that the pooled mean consumption expenditure per adult equivalent of the adopter farmers was higher compared to non-adopters.

\subsection{Technology Adoption, Cereals Productivity and Welfare}

The impact of various technology sets on net cereal crops income per cultivated land (an indicator of cereal crops productivity) and welfare is estimated by using MESR model, and it is presented Table 3. The study was not able to estimate the impact of adoptions of improved seed varieties because of the small size of farmers who adopted only improved seed varieties. The net cereal crop income per cultivated land for mixed adopters of improved seed variety with row planting technology was about birr 14479.64 compared to non-adopter farmers. In addition, simultaneous adoption of improved seed and row planting technology 
Table 2. Summary statistics for household welfare and cereal crop productivity by technology sets

\begin{tabular}{llllllllll}
\hline \multirow{2}{*}{$\begin{array}{l}\text { Outcome } \\
\text { variables }\end{array}$} & A0 & A1 & A2 & A3 & A4 & A5 & A6 & A7 & Total \\
\cline { 2 - 10 } Consumption & 1739.9 & 2783.7 & 2284.2 & 1941.9 & 1931.6 & 2024.3 & 476.5 & 2090.2 & 1859.8 \\
per AE & $(1030.9)$ & $(1104.3)$ & $(1230.3)$ & $(1263.0)$ & $(926.1)$ & $(1092.9)$ & $(99.59)$ & $(1007.4)$ & $(1117.4)$ \\
Net cereal & 9604.1 & 14181.7 & 12521.3 & 10541.3 & 24679.3 & 8646.3 & 15144.3 & 12543.1 & 12295.4 \\
income per ha & $(8385.5)$ & $(14524.4)$ & $(10194.2)$ & $(10081.2)$ & $(20123.7)$ & $(4207.7)$ & $(11891.8)$ & $(10826.7)$ & $(11655.6)$ \\
Observations & 150 & 21 & 30 & 27 & 34 & 33 & 30 & 75 & 400 \\
\hline
\end{tabular}

Source: Computed result (2020)

increased farmers' net cereal crops income per cultivated land size by $141.96 \%$. The result indicates crop farmers who used both adaptation strategies at a time gained more reward from their produced compared to other improved agricultural technologies. Besides, this result indicates the role of using a combination of different improved agricultural production technologies for a better farm income. Compared to cereal producing farmers who used row planting technology, those who used a combination of row planting and improved seed variety received an additional of birr 13,554.8.

Table 3. Actual, counterfactual outcome and impact of technology sets on net cereal crops income per cultivated land and consumption expenditure per adult equivalent

\begin{tabular}{|c|c|c|c|c|c|c|}
\hline \multirow{2}{*}{ Technology set } & \multicolumn{3}{|c|}{ Cereal crops productivity } & \multicolumn{3}{|l|}{ Welfare } \\
\hline & $\begin{array}{l}\text { Actual } \\
\text { outcome } \\
(\mathrm{AO})\end{array}$ & $\begin{array}{l}\text { Counterfactual } \\
\text { outcome }(\mathrm{CO})\end{array}$ & $\begin{array}{l}\text { Impact } \\
(\mathrm{ATT}) \\
(\mathrm{AO}-\mathrm{CO})\end{array}$ & $\begin{array}{l}\text { Actual } \\
\text { outcome } \\
(\mathrm{AO})\end{array}$ & $\begin{array}{l}\text { Counterfactual } \\
\text { outcome }(\mathrm{CO})\end{array}$ & $\begin{array}{l}\text { Impact } \\
(\mathrm{ATT}) \\
(\mathrm{AO}-\mathrm{CO})\end{array}$ \\
\hline Improved seed only & - & - & - & & & \\
\hline Row planting only & $\begin{array}{l}12521.28 \\
(1570.157)\end{array}$ & $\begin{array}{l}11596.44 \\
(943.5075)\end{array}$ & $\begin{array}{l}924.8404 \\
(1831.83)\end{array}$ & $\begin{array}{l}2284.219 \\
(222.0361)\end{array}$ & $\begin{array}{l}1716.526 \\
(158.4078)\end{array}$ & $\begin{array}{l}567.6932^{\star *} \\
(272.7509)\end{array}$ \\
\hline Urea after weeding only & $\begin{array}{l}10541.28 \\
(1359.804)\end{array}$ & $\begin{array}{l}7856.311 \\
(1123.852)\end{array}$ & $\begin{array}{l}2684.965 \\
(1764.117)\end{array}$ & $\begin{array}{l}1941.855 \\
(231.4655)\end{array}$ & $\begin{array}{l}1543.843 \\
(179.4666)\end{array}$ & $\begin{array}{l}398.0128 \\
(292.8899)\end{array}$ \\
\hline $\begin{array}{l}\text { Improved seed \& Row } \\
\text { planting }\end{array}$ & $\begin{array}{l}24679.25 \\
(3431.022)\end{array}$ & $\begin{array}{l}10199.62 \\
(746.6655)\end{array}$ & $\begin{array}{l}14479.64^{* * *} \\
(3511.327)\end{array}$ & $\begin{array}{l}1931.593 \\
(156.4431)\end{array}$ & $\begin{array}{l}2145.299 \\
(152.9386)\end{array}$ & $\begin{array}{l}-213.7062 \\
(218.7799)\end{array}$ \\
\hline $\begin{array}{l}\text { Improved seed \& Urea after } \\
\text { weeding }\end{array}$ & $\begin{array}{l}8646.279 \\
(727.8556)\end{array}$ & $\begin{array}{l}10255.36 \\
(528.9636)\end{array}$ & $\begin{array}{l}-1609.077^{*} \\
(899.7646)\end{array}$ & $\begin{array}{l}2024.342 \\
(190.1292)\end{array}$ & $\begin{array}{l}1620.814 \\
(196.108)\end{array}$ & $\begin{array}{l}403.5283 \\
(273.1437)\end{array}$ \\
\hline $\begin{array}{l}\text { Row planting \& Urea after } \\
\text { weeding }\end{array}$ & $\begin{array}{l}15144.28 \\
(2155.084)\end{array}$ & $\begin{array}{l}10798.54 \\
(903.0299)\end{array}$ & $\begin{array}{l}4345.737^{\star} \\
(2336.632)\end{array}$ & $\begin{array}{l}476.5395 \\
(16.64231)\end{array}$ & $\begin{array}{l}228.329 \\
(83.02373)\end{array}$ & $\begin{array}{l}248.2105^{* * *} \\
(84.6753)\end{array}$ \\
\hline $\begin{array}{l}\text { Improved seed, Row } \\
\text { planting \& Urea after } \\
\text { weeding }\end{array}$ & $\begin{array}{l}12543.11 \\
(816.1512)\end{array}$ & $\begin{array}{l}10658.96 \\
(523.2079)\end{array}$ & $\begin{array}{l}1884.147^{\star} \\
(969.4582)\end{array}$ & $\begin{array}{l}2090.211 \\
(91.39321)\end{array}$ & $\begin{array}{l}1732.123 \\
(117.5997)\end{array}$ & $\begin{array}{l}358.0882^{\star *} \\
(148.9376)\end{array}$ \\
\hline
\end{tabular}

Source: Model result (2020); Standard errors in parentheses $\left({ }^{\star} \mathrm{p}<0.10,{ }^{* *} \mathrm{p}<0.05,{ }^{* *} \mathrm{p}<0.01\right)$

The adoption of row-planting technology mixed with urea after weeding increased the net cereal crop income per cultivated land by birr 4345.8 for adopters compared to that of non-adopter cereal producing farmers. It has the potential to increase net cereal crops income per cultivated land farmer by $40.24 \%$. This result also indicates the possible advantage of using urea after weeding with row planting technology as it showed a net crop income difference of birr2403.88. Compared to non-adopter, simultaneous adoption of improved seed, row planting and urea after weeding increased net cereal crop income per cultivated land by Birr 1884.15. The result shows that the use of a combination of technologies improves net cereals crop income, but the decision to which technologies are used at a time affects the total net cereals crop income and possible advantages from cost benefit issues from using different technologies. This result is in agreement with ${ }^{(27)}$ found that full-package technologies adopters received better income than partial technology adopters and non-adopters. Also, the study result confirms that partial adopters received better income than non-adopters as well. Besides, a study by ${ }^{(28)}$ revealed, on average, adopters of a combination of SAPs received between 43 and 75-percent income more than that of the non-adopters.

Conversely, the study reveals that combined use of improved agricultural technologies have also a negative effect on net cereals crop income per cultivated land. For instance, the use of improved seed and urea after weeding decreases farmers net crop income and it was significant at $10 \%$ level. In the study area, the net crop income of farmers who used improved varieties 
and applied urea after weeding decreases farmers net crop income by birr 1609.077 per cultivated land for adopters compared to the counterfactual scenario of non-adopter. Such unbelievable results could happen due poor agronomic practices and other management issues. The result indicates using a combination of technologies requires experience and background knowledge on technology choice, recommended rate and time (Table 3).

The finding indicates that simultaneous adoption of row planting technology and urea after weeding increases consumption expenditure by about birr 248.21 per adult equivalent for adopters compared to the counterfactual scenario of non-adopter. The adoption of row planting technology alone showed relatively more impact on farmers' consumption expenditure per adult equivalent. For instance, the consumption expenditure per adult equivalent increases by Birr 567.69 for adopters of row planting compared to the counterfactual scenario of non-adopter. This result indicates household are more likely spent per adult equivalent when they used row-planting technology with urea after weeding. The previous result in this study obtained a better net crop income when they used row-planting technology and urea after weeding and this income increase the probability of household's expenditure in the study area. The finding by ${ }^{(29,30)}$ agreed with this result.

The result revealed that simultaneous adoption of improved seed, row planting, and urea after weeding were positively and significantly affect the consumption expenditure per adult equivalent at $\mathrm{p}<0.05$. This increases consumption expenditure by about Birr 358.09 per adult equivalent for adopters compared to a counterfactual scenario of non-adopter. Alternatively, it increases consumption expenditure per adult equivalent by $20.67 \%$ for adopters compared to the counterfactual scenario of non-adopter. The previous studies by ${ }^{(31,32)}$ who revealed the assenting role of improved agricultural production technologies on farmers' expenditure per adult equivalent welfare supports these findings. The result indicates the role of improved agricultural production technologies for improving farmer's welfare through improving productivity, farmers gain and farmers purchasing power as well.

\section{Conclusions}

The study finds that, usually, simultaneous adoption of technologies imposed a positive impact on cereal crops productivity and welfare of cereal producing farmers. For instance, simultaneous adoption of improved seed and row planting, row planting and urea, and improved seed, row planting, and urea improved adopter farmers net cereal crop income per cultivated land size compared to a counterfactual scenario of non-adopter. Furthermore, the study finds that adoption of row planting technology, a combination of row planting and urea after weeding, and a combination of improved seed, row planting, and urea after weeding showed a positive impact on farmer's welfare. Except for the adopters of row planting technology, using a combination of other technology sets had higher welfare gain compared to a counterfactual scenario of non-adopter. Special focus on cluster farming, which is a potential strategy to exploit farmers' potential in the adoption of multiple technologies, is required. Besides, future studies could extend the scope of the analysis by using carefully planned household surveys that capture in-depth and detailed data using panel data.

\section{References}

1) Mekonen T, Karelplein K. 2017. Available from: https://www.merit.unu.edu/publications/wppdf/2017/wp2017-007.pdf.

2) . 2021. Available from: https://www.usaid.gov/ethiopia/food-assistance.

3) Shikur ZH. Agricultural policies, agricultural production and rural households' welfare in Ethiopia. Journal of Economic Structures. 2020;9(1):1-21. Available from: https://dx.doi.org/10.1186/s40008-020-00228-y. doi:10.1186/s40008-020-00228-y.

4) Workineh A, Tayech L, Ehite HK. Agricultural technology adoption and its impact on smallholder farmers welfare in Ethiopia. African Journal of Agricultural Research. 2020;15(3):431-445. Available from: https://dx.doi.org/10.5897/ajar2019.14302. doi:10.5897/ajar2019.14302.

5) Ketema M, Kassa B. Impact of Technology on Smallholder Wheat Production in Bale Highlands of Ethiopia: Application of Output Decomposition Model. Turkish Journal of Agriculture - Food Science and Technology. 2016;4(6):446-446. Available from: https://dx.doi.org/10.24925/turjaf.v4i6.446-454.593. doi:10.24925/turjaf.v4i6.446-454.593.

6) Bezu S, Kassie GT, Shiferaw B, Ricker-Gilbert J. Impact of Improved Maize Adoption on Welfare of Farm Households in Malawi: A Panel Data Analysis. World Development. 2014;59:120-131. Available from: https://dx.doi.org/10.1016/j.worlddev.2014.01.023. doi:10.1016/j.worlddev.2014.01.023.

7) Kariyasa K, Dewi YA. Analysis of factors affecting adoption of integrated crop management farmer field school (icm-ffs) in swampy areas. International Journal of Food and Agricultural Economics. 2013;1(2):29-38.

8) Solomon Y. Adoption of Improved Agricultural Technologies in Developing Countries: Literature Review. International Journal of the Science of Food and Agriculture. 2020;4(2):183-190.

9) Workineh A, Tayech L, Ehite HK. Agricultural technology adoption and its impact on smallholder farmers welfare in Ethiopia. African Journal of Agricultural Research. 2020;15(3):431-445. Available from: https://dx.doi.org/10.5897/ajar2019.14302. doi:10.5897/ajar2019.14302.

10) Wordofa MG, Hassen JY, Endris GS, Aweke CS, Moges DK, Rorisa DT. Adoption of improved agricultural technology and its impact on household income: a propensity score matching estimation in eastern Ethiopia. Agriculture \& Food Security. 2021;10(1). Available from: https://dx.doi.org/10.1186/s40066020-00278-2. doi:10.1186/s40066-020-00278-2.

11) Kassie M, Marenya P, Tessema Y, Jaleta M, Zeng D, Erenstein O, et al. Measuring Farm and Market Level Economic Impacts of Improved Maize Production Technologies in Ethiopia: Evidence from Panel Data. Journal of Agricultural Economics. 2018;69(1):76-95. Available from: https://dx.doi.org/10.1111/ 
1477-9552.12221. doi:10.1111/1477-9552.12221.

12) Menasbo G, Stein T, Holden, Frode A. 2021. Available from: https://doi.org/10.1186/s40100-021-00184-6.

13) Biru WD, Zeller M, Loos TK. The Impact of Agricultural Technologies on Poverty and Vulnerability of Smallholders in Ethiopia: A Panel Data Analysis. Social Indicators Research. 2020;147(2):517-544. Available from: https://dx.doi.org/10.1007/s11205-019-02166-0. doi:10.1007/s11205-019-02166-0.

14) Leiber T. Impact evaluation of quality management in higher education: a contribution to sustainable quality development in knowledge societies. European Journal of Higher Education. 2018;8(3):235-248. Available from: https://dx.doi.org/10.1080/21568235.2018.1474775. doi:10.1080/21568235.2018.1474775.

15) Agricultural Sample Survey Report on Area and Production of Major Crops. Statistical Bulletin. 2017;532.

16) Bidzakin JK, Fialor SC, Awunyo-Vitor D, Yahaya I. 2019. Available from: http://dx.doi.org/10.1080/23322039.2019.1618229.

17) ZFED (Zone Finance and Economic Development). Finance and Economic Development of North Shewa Zone. Unpublished source. Fiche, Ethiopia. 2018.

18) Teferi GB, Getamesay BM. The Effect of Transaction Cost on Cereal and Pulse Crops producer farmers in Salale (North Shewa Zone), (Ethiopia). International Journal of Current Research. 2018;10(1):64793-64802.

19) Lajqi S, Thaqi M, Kaçiu K, Bytyqi H, Krasniqi B. Impact of agricultural intervention programs on income and employment: evidence from vegetable sector in kosovo. EKONMISAO I PRAKSA DBKGOD. 2017;XXVI:561-592.

20) Ma W, Abdulai A. Does cooperative membership improve household welfare? Evidence from apple farmers in China. Food Policy. 2016;58(3):94-102. Available from: https://dx.doi.org/10.1016/j.foodpol.2015.12.002. doi:10.1016/j.foodpol.2015.12.002.

21) Ahmed MH, Geleta KM, Tazeze A, Andualem E. The Impact of improved maize varieties on farm productivity and wellbeing: evidence from the East Hararghe Zone of Ethiopia. Development Studies Research. 2017;4(1):9-21. Available from: https://dx.doi.org/10.1080/21665095.2017.1400393. doi:10.1080/21665095.2017.1400393.

22) Falco SD, Veronesi M. How Can African Agriculture Adapt to Climate Change? A Counterfactual Analysis from Ethiopia. Land Economics. 2013;89(4):743-766. Available from: https://dx.doi.org/10.3368/le.89.4.743.

23) Koppmair S, Kassie M, Qaim M. Farm production, market access and dietary diversity in Malawi. Public Health Nutrition. 2017;20(2):325-335. Available from: https://dx.doi.org/10.1017/s1368980016002135.

24) Kassie M, Teklewold H, Jaleta M, Marenya P, Erenstein O. Understanding the adoption of a portfolio of sustainable intensification practices in eastern and southern Africa. Land Use Policy. 2015;42(1):400-411. doi:10.1016/j.landusepol.2014.08.016.

25) Teklewold H, Kassie M, Shiferaw B. Adoption of Multiple Sustainable Agricultural Practices in Rural Ethiopia. Journal of Agricultural Economics. 2013;64(3):597-623. doi:10.1111/1477-9552.12011.

26) Tesfaye W, Tirivayi N. The impacts of postharvest storage innovations on food security and welfare in Ethiopia. Food Policy. 2018;75(3):52-67. Available from: https://dx.doi.org/10.1016/j.foodpol.2018.01.004.

27) Menale K, Moti J, Paswel M. Impact of improved maize variety adoption on household food security in Ethiopia: an endogenous switching regression approach. In: International Conference of Agricultural Economists. 2015. Available from: https://link.springer.com/article/10.1007/s12571-017-0759. doi:10.1007/s12571-017-0759.

28) Khonje M, Manda J, Alene AD, Kassie M. Analysis of Adoption and Impacts of Improved Maize Varieties in Eastern Zambia. World Development. 2015;66:695-706. doi:10.1016/j.worlddev.2014.09.008.

29) Tesfaye S, Bedada B, Mesay Y. Impact of improved wheat technology adoption on productivity and income in Ethiopia. African Crop Science Journal. 2016;24(1):127-135. doi:10.4314/acsj.v24i1.14s.

30) Dhrifi A. Agricultural Productivity and Poverty Alleviation: What Role for Technological Innovation. Journal of Economic and Social Studies. 2014;4(1):131-151. doi:10.14706/jecoss11418.

31) Sileshi M, Kadigi R, Mutabazi K, Sieber S. Impact of soil and water conservation practices on household vulnerability to food insecurity in eastern Ethiopia: endogenous switching regression and propensity score matching approach. Food Security. 2019;11(4):797-815. doi:10.1007/s12571-019-00943-w.

32) Yirga C, Dawit A. Adoption of crop technologies among Smallholder Farmers in Ethiopia: Implications for Research and Development. Ethiopian Journal of Agriculture Science. 2016. Available from: https://www.researchgate.net/publication/311912479. 